\title{
RESTAURATIE VAN EEN JAPANS LADEKASTJE
}

Kleine ladekastjes uit Japan (tansu) waren vervaardigd als sierobject en werden waarschijnlijk gebruikt voor het opbergen van curiosa en sieraden. In 2015 werd een klein Japans ladekastje ter restauratie aangeboden in mijn atelier (afb. I). Het kastje is in particulier bezit. De huidige eigenaar heeft het kastje in het verleden gekocht op een veiling. Het kastje past in de traditie van de Japanse ladekast die in de Edo-periode (I603-I867) in zwang kwam, vooral onder de gewone Japanners.

\section{Ontstaan en ontwikkeling van de Japanse ladekast}

Het Chinese woord dansi verwees oorspronkelijk naar een vierkant kistje met benodigdheden voor de theeceremonie, dat op de schouder kon worden vervoerd. Later werd het woord tansu in Japan synoniem met de ladekast, een uitvinding van eigen bodem.

De Japanse ladekasten werden aanvankelijk vooral gebruikt voor het opbergen van kleding, die altijd liggend werd bewaard. Het bestuur van de shoguns in Edo, het huidige Tokyo, bracht vrede en stabiliteit en daarmee meer welvaart onder bredere lagen van de bevolking. De productie van stoffen werd goedkoper en vanaf de tweede helft van de ${ } 7^{\mathrm{e}}$ eeuw hadden ook de minder rijken zoveel kleding dat ze behoefte kregen aan opbergruimte. De welgestelde bovenlaag had dat probleem niet: hun huizen waren ruim genoeg voor de dozen en kisten waarin hun bedienden hun talloze kimono's en gewaden van oudsher opborgen.

Voor de krapper behuisden boden de tansu echter uitkomst: ze namen minder ruimte in beslag en de laden maakten ordening mogelijk, zodat de kleding gemakkelijk terug te vinden was, ook zonder personeel: het was nu niet meer nodig eerst alles uit de kist of doos te halen om het gezochte kledingstuk te vinden. Dankzij de verbeterde infrastructuur en het ontstaan van grotere specialisatie in houtbewerking in de Edo-periode kon bovendien voorbewerkt en op maat gezaagd hout uit verschillende delen van het land worden aangevoerd. Daardoor werd de productie van de tansu grootschaliger en goedkoper en kwamen de ladekasten binnen het bereik van steeds meer mensen. Tijdens de daarop volgende Meiji-periode (I868-I9I2) werden infrastructuur en houtbewerking verder verbeterd. Vanaf die tijd mochten ook de lagere klassen luxe producten hebben. De productie en distributie van de tansu nam een nog hogere vlucht, ook onder invloed van technologische vernieuwingen uit de VS en Europa.

De tansu werden allang niet meer alleen voor het opbergen van kleding

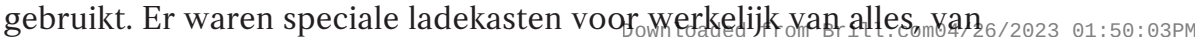




\section{Afb. 1}

Tansu, voorzijde voor restauratie, zelkova en moerbeihout, 54,4 $\mathrm{x}$ $60 \times 32,5 \mathrm{~cm}$, Japan, late Edo- of vroege Meiji-tijd, 1825-188o. Privécollectie

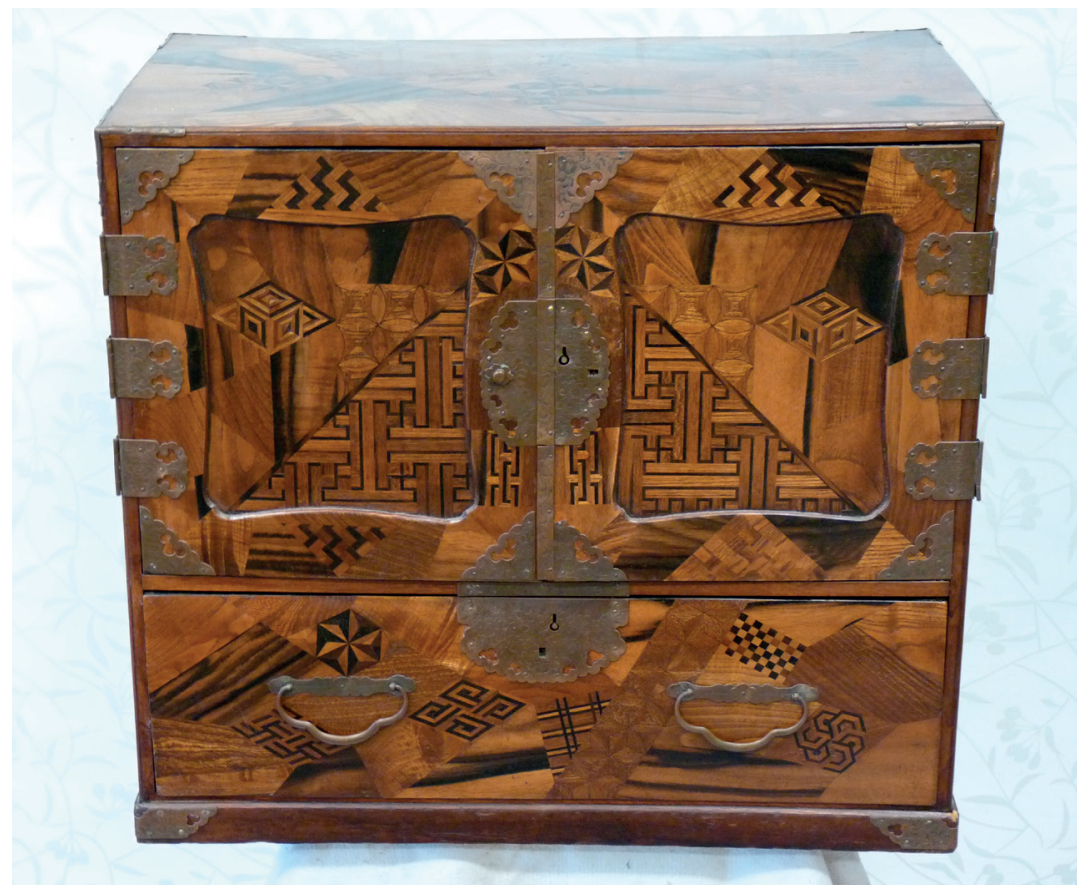

medicijnen en schrijfgerei tot documenten, sieraden en benodigdheden voor de theeceremonie. Ook de vormgeving werd verfijnder en tansu werden geliefde objecten voor de rijkere Japanners en buitenlandse diplomaten en bezoekers. ${ }^{1}$

\section{Datering en herkomst}

Dit kastje stamt waarschijnlijk uit de late Edo- of vroege Meiji-tijd, tussen I825 en I88o. Dit valt af te leiden uit de parqueterietechniek waarmee het is gedecoreerd. Dit type parqueterie staat bekend als ran-yosegi of 'random parquetry' en werd vanaf het begin van de ${ }^{2}{ }^{\mathrm{e}}$ eeuw toegepast door handwerklieden in de steden Shizuoka en Hakone. Ze legden stukjes van verschillende houtsoorten zoals zelkova en moerbeihout in een patroon waarbij de nerven en kleuren van de gebruikte houtsoorten zo goed mogelijk tot hun recht kwamen. Hierin werden vervolgens kleine geometrische parketmotieven ingelegd. Dit kastje is hier een goed voorbeeld van. Vanaf $1875 \mathrm{kwam}$ een nieuwe parqueterietechniek in zwang met meer complexe, aaneengesloten geometrische patronen (yosegi, of 'parquetry') en werden kastjes met uitsluitend ran-yosegi decoratie zeldzamer. $^{2}$

Hoogstwaarschijnlijk komt dit kastje uit Hakone, dat al snel het belangrijkste centrum voor parqueterie werd. Hakone werd steeds populairder onder de Japanse en buitenlandse diplomaten, zakenlui en toeristen die vanuit het nabijgelegen Yokohama graag een uitstapje maakten naar deze koele bergplaats met zijn vele heetwaterbronnen en goede hotels. Mogelijk heeft dit kastje via een buitenlandse diplomaat of toerist zijn weg gevonden naar het Westen. Het betreft echter een

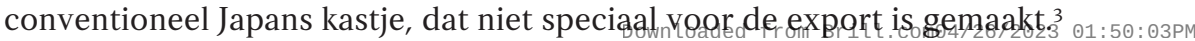


- Constructie

Het hout dat gebruikt is voor de constructie - ook wel blindhout genoemd ${ }^{4}$ - onder het fineer, is een naaldhoutsoort. Er zijn op de verschillende constructieve onderdelen geen resten van lijm aangetroffen. De verschillende delen zijn samengevoegd met ronde bamboe pennen. Met uitzondering van de deurtjes zijn alle onderdelen van het kastje aan één zijde gefineerd. Door het ontbreken van tegenfineer is het blindhout gaan 'werken'. ${ }^{5}$ De bovenkant en onderkant, achterkant en zijdes zijn door krimp gaan golven en bij de ontmoeting tussen deze delen is plaatselijk een enorme spanning ontstaan. Dit heeft geleid tot breuken langs de randen, in het bijzonder aan de zijkanten van de bovenzijde. Door deze krimp konden ook de lades niet goed sluiten. Ten opzichte van het binnenwerk bleken ze vijf millimeter uit te steken. Daarnaast was, door een naar binnen 'golvende' zijde, een van de lades te breed om nog geopend of gesloten te kunnen worden.

\section{- Afwerking}

Het kastje is aan de buitenzijde afgewerkt met een in alcohol oplosbare lak. Aan de bovenzijde zijn door vocht kringen ontstaan in de afwerking en is een deel van de lak verdwenen. Afgezien van wat vuil en doffe plekken was de afwerking op de rest van het kastje nog in goede staat.

\section{- Beslag}

Bij het verwijderen van het beslag bleken op alle grotere en kleinere delen aan de binnenzijde resten van een oorspronkelijke verzilvering nog aanwezig (afb. 2). Aan de buitenzijde is deze verzilvering geheel weggepoetst. Er ontbraken een paar kleine knopjes en een hoekje van het sierbeslag op het deurtje.

\footnotetext{
Afb. 2

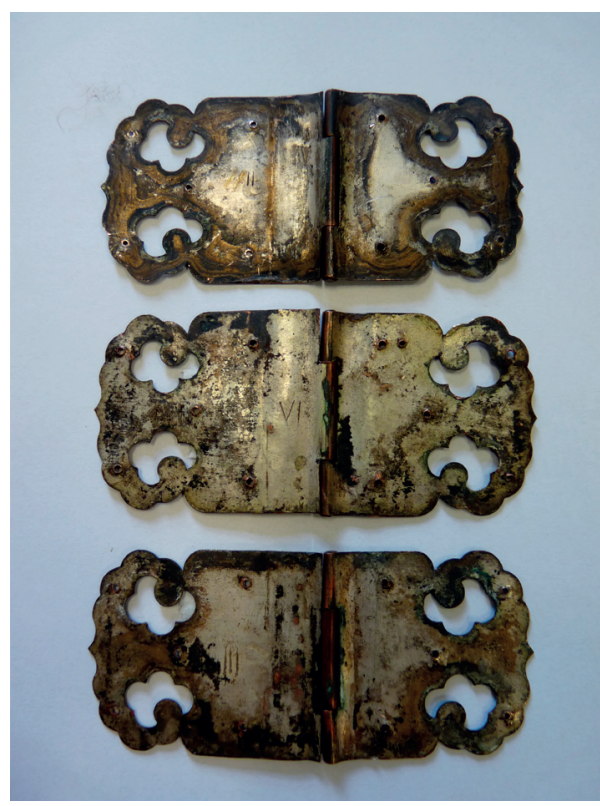


Afb. 3

Linkerzijde met gedeeltelijk losse vulsels van stopwas

Afb. 4

Een kleine lade met gedemonteerde zijde
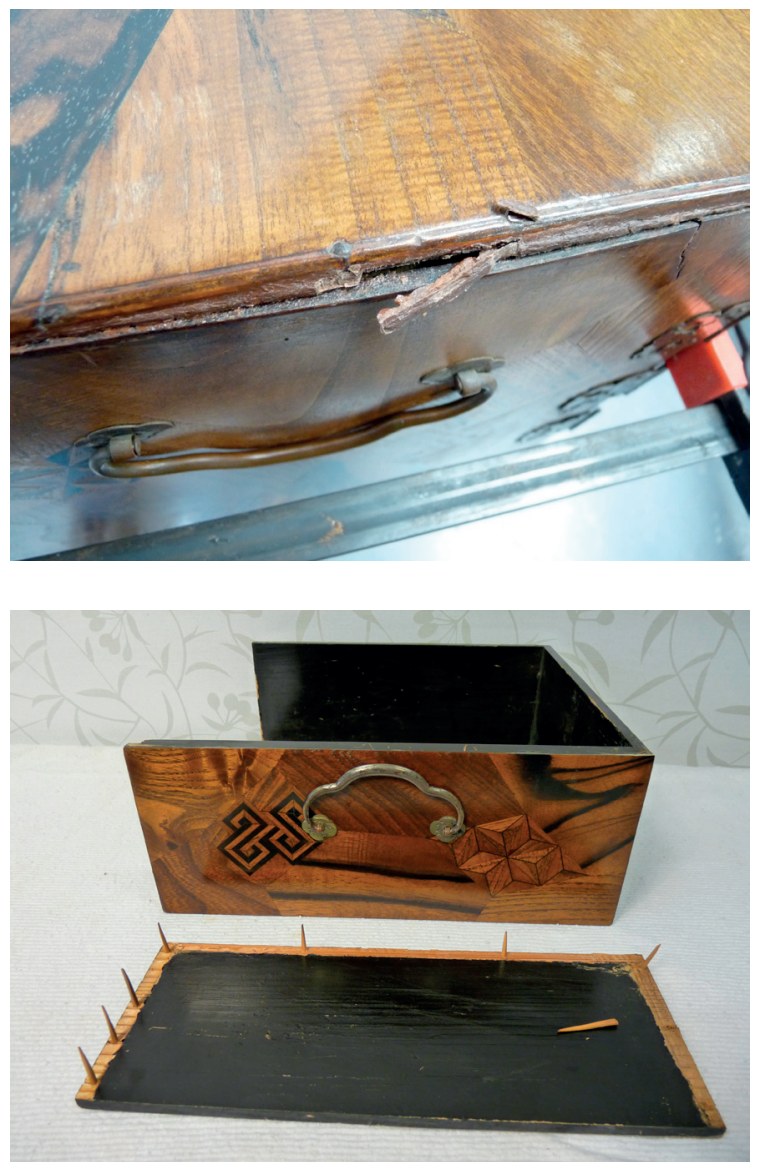

\section{- Zichtbare eerdere restauratie}

Het kastje is in het verleden al eens 'optisch' gerestaureerd. De breuken aan de randen, waarbij delen van het kwartronde lijstwerk verloren zijn gegaan, zijn daarbij gevuld met een aangekleurde stopwas (afb. 3).

\section{Restauratie}

Op verzoek van de huidige eigenaar is het uitgangspunt bij de restauratie geweest dat het kastje weer gebruikt kan worden. Met de bedoeling dat men de deurtjes en de lades weer goed zou kunnen openen en sluiten. Daarnaast is ervoor gekozen om het originele concept van het kastje, het verzilverde beslag dat mooi afsteekt tegen de bruine tinten van de parqueterie, weer in ere te herstellen.

\section{- Constructie}

Het meest ingrijpende onderdeel van de restauratie was het werk aan de lades. Om ervoor te zorgen dat de lades weer in de binnenzijde zouden passen (ze staken vijf millimeter naar buiten), is het binnenwerk naar voren gehaald. Het binnenwerk zat, zonder lijm, vast in groeven in de zijdes, boven- en onderkant. Deze groeven zijn aan de voorzijde vijf millimeter verlengd, zodat het binnenwerk in zijn geheel naar voren getrokken kon worden. 
Voor het weer lopend maken van de te groot geworden lade is deze gedeeltelijk gedemonteerd (afb. 4) waardoor ook de constructie met ronde bamboepennen goed zichtbaar werd. De voor- en achterzijde van de lade zijn I,5 millimeter ingekort. Daarna is de zijde weer gemonteerd met de originele pennetjes.

In eerste instantie was het de bedoeling te proberen de wijkende delen aan de buitenzijde weer enigszins bij elkaar te brengen en deze vervolgens weer te consolideren met bamboe pennetjes. Na verwijdering van de stopwas zijn de verschillende delen zorgvuldig schoongemaakt en aangesmeerd met een laagje verdunde beenderlijm. Een dergelijke laag wordt in de restauratie wel vaker gebruikt als buffer tussen het hout en een moderne (lees: niet reversibele) epoxylijm waarmee de delen daarna samengevoegd zijn. De spanning bleek echter toch te groot en nog geen 48 uur na het verwijderen van de lijmklemmen scheurde het geheel toch weer open. Dankzij de buffer van beenderlijm konden alle lijmresten weer geheel verwijderd worden.

Uiteindelijk bleken de scheuren bedreigend voor het voortbestaan van het kastje. Daarom is besloten de openstaande stukjes aan de rand op te vullen met een notenhouten, op maat aangepast lijstje dat qua nerf en tekening goed aansloot bij de nog aanwezige delen van het kwartronde lijstje.

\section{- Afwerking}

Alleen van de bovenzijde van het kastje is de aangetaste laklaag mechanisch verwijderd met ethanol (95\%) en een zeer fijne schuurvlies. Hierdoor verdwenen alle vlekken en kringen. De waterschade was nog niet doorgedrongen tot het hout zelf. Daarna is op dit deel, draaiend met een dot, een politoerlaag op basis van schellak aangebracht. De afwerking op de overige delen van het kastje is met een popote opnieuw gepolijst. ${ }^{6}$ Daarna is de politoerafwerking op de bovenkant met heel fijne staalwol terug geslepen tot de gewenste glansgraad passend bij de rest van het kastje.

\section{- Beslag}

Het beslag van 60 delen, bestaande uit scharnieren, hoekbeslag, handvatten, sierbeslag en knopjes, is - voor zover dit nog niet het geval was - gemerkt. Twee ontbrekende knopjes en een ontbrekend stukje van het sierbeslag zijn bijgemaakt. Deze, alsook alle kleine nageltjes, waarmee het beslag oorspronkelijk was vastgezet, zijn door een gespecialiseerd bedrijf opnieuw elektrolytisch verzilverd en chemisch verouderd. $\mathrm{Na}$ montage op het meubel zijn alle delen voorzien van een dunne laag microkristallijne was.

- Godelieve van Wees is afgestudeerd aan de opleiding Sinologie (1984). In 1993 startte zij een 4-jarige opleiding tot houtrestaurator in Amsterdam (HMC). Tijdens haar opleiding liep zij stage bij de Rijksdienst Beeldende Kunst (huidig ICN). Sinds 1997 werkt zij als zelfstandig restaurator, onder de naam Le Singe Violet, in Leiden. Zij restaureert met name houten meubelen en (kunst) objecten, zowel voor musea als voor particulieren. 


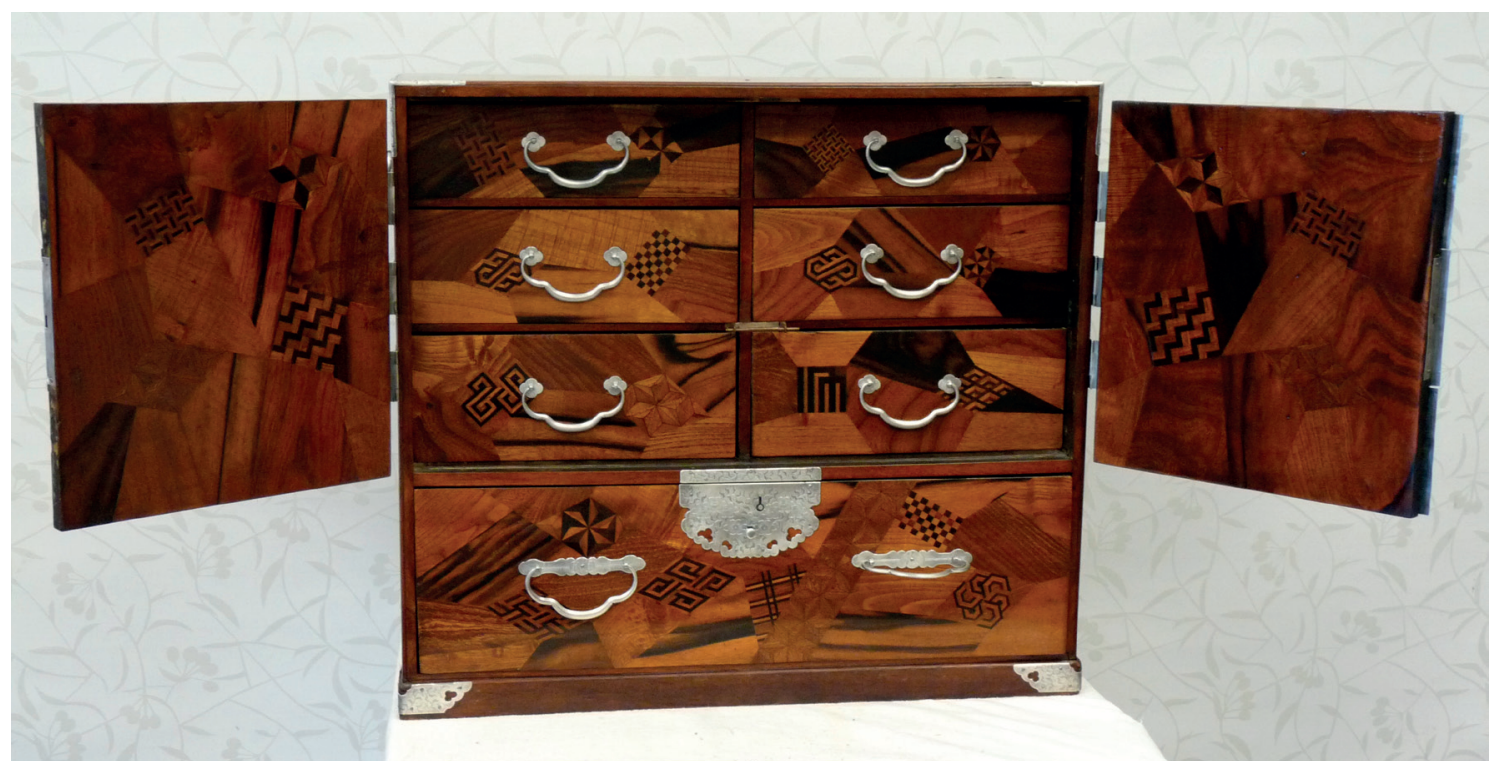

Afb. 5

Het kastje na

restauratie

\section{LITERATUUR}

Koizumi Kazuko, Traditional Japanese Chests: A Definitive Guide, Kodansha International, Tokyo, 2010.

Yamamori Yumiko, Japanese Export Furniture, with particular emphasis on the Meiji Era (I868-I9I2), webpublicatie, 1999. (http://www.euronet.nl/users/artnv/ japanexport.html)

\section{NOTEN}

* Met dank aan Gertie Mulder.

I Koizumi 20I0: 98-I06.

2 Yamamori 1999: hoofdstuk IV sub b.

3 Bevestigd in persoonlijke e-mail van Mw. Yamamori Yumiko, 2016.

4 Indien een meubel van een goedkopere houtsoort wordt vervaardigd en vervolgens met fineer van een andere (duurdere) houtsoort wordt bedekt, noemt men het bedekte hout 'blindhout'.

5 In de Europese meubelkunst is het gebruikelijk om het hout tweezijdig te fineren. Door deze tweezijdige opsluiting van het hout wordt de werking van het blindhout geminimaliseerd. Het fineer aan de binnenzijde is meestal een goedkope fineersoort, en wordt ook wel tegenfineer genoemd.

6 Popote is een emulsie met een polijstende werking, onder andere door de hierin aanwezige kleine hoeveelheid tripelaarde. 